ORCID: 0000-0002-0032-9944

Uniwersytet Warmińsko-Mazurski w Olsztynie

marzenna.nowicka@uwm.edu.pl

\title{
W świecie poznanych i ,niepoznanych" liter, czyli o kontynuacji bezsensów w instytucjonalnych praktykach nauki czytania i pisania dzieci
}

\begin{abstract}
Czy nie jest rodzajem schizofrenii administracyjnej sytuacja, w której instytucja powołana do zapewniania rozwoju dzieci używa narzędzi do jego limitowania, blokowania i zatrzymywania?

Komu i dlaczego zależy na tym, by dzieci wolniej uczyły się czytać?
\end{abstract}

Klus-Stańska, Nowicka (2013: 25)

\section{Summary}

In the world of known and "unknown" letters, that is about the continuation of nonsense in institutional practices of learning children to read and to write

Reading is a key competence in a social functioning. In the Polish educational system both kindergarten and school, are responsible for the effects of learning this skill. The article presents the results of research on the content of textbooks and methodological guides intended for the basic reading course for children aged six and seven. As a result of the comparison, it was found that the literacy process was doubled at the school level according to the scheme in force in the kindergarten. The page layout for entering a new letter and the suggested exercises are repeated in the textbooks. The same process for introducing a new letter is valid at the kindergarten and on the school level. The texts for learning to read are trivial, and the instructions formulated to them block the development of reading skills at the semantic and critical-creative level.

Keywords: learning to read in kindergarten, learning to read at school, textbooks, methodological guides

Słowa kluczowe: nauka czytania w przedszkolu, nauka czytania w szkole, podręczniki, przewodniki metodyczne 
Wprowadzanie dzieci w świat pisma zawsze odbywa się w określonym kontekście kulturowym. Dynamiczne przemiany społeczne, obyczajowe, technologiczne rozszerzają i głęboko zmieniają środowisko nieformalnej alfabetyzacji dzieci. Obserwowany w ostatnich dwóch dekadach ogromny rozkwit rynku książki dla najmłodszych, sposobów jej dystrybucji i reklamy, a także kampanie społeczne promujące czytelnictwo nie tylko spowodowały obniżenie wieku inicjacji czytelniczej, ale ugruntowały alfabetyzacyjne znaczenie i podniosły jakość pierwszych kontaktów dziecka z książką (Centner-Guz 2017). Obok intensywnego rozrostu oferty wydawniczej, szczególnym źródłem bodźców do nauki czytania i pisania jest też rozwój nowych mediów. Współczesne dzieci urodzone po 2010 r. to pokolenie Alpha (McCrindle 2020), czyli pierwsza generacja, która ukształtowała się w erze przenośnych urządzeń cyfrowych i której codzienność właściwie już od dnia narodzin jest zdominowana przez nowe technologie. Już bardzo małe dzieci posiadają własne smartfony i tablety, 25\% trzy- i czterolatków dysponuje takim urządzeniem (Bąk 2015: 8-10). Co 5 dziecko w wieku trzech lat korzysta z internetu, a z wiekiem odsetek ten rośnie: z sieci korzysta 36\% czterolatków i 70\% sześciolatków (Batorski 2017: 80). Z perspektywy edukacyjnej ważne jest, że korzystanie z urządzeń technicznych przyspiesza i gruntuje proces alfabetyzacji dzieci, co potwierdzają prowadzone testy sprawności językowych (Klichowski i in. 2017: 119). W swoich badaniach obejmujących populację sześciolatków w Polsce Grażyna Krasowicz-Kupis (2006: 35) wskazuje, że dzieci korzystające z komputera i internetu lepiej znają litery, poprawniej i efektywniej czytają. Na spontaniczny i nieformalny proces alfabetyzacji nakłada się systematyczne oddziaływanie instytucji przedszkola i szkoły, bowiem mimo utraty prymatu są one nadal odpowiedzialne za powodzenie tego procesu. Nie jest to łatwe zadanie, ponieważ nauczyciele muszą się zmierzyć z tym, że poznawanie pisma w sytuacjach pozadydaktycznych wiąże się zazwyczaj z bardzo interesującym dla dzieci kontekstem, angażuje je bezpośrednio i wielozmysłowo. Mając na względzie jakość edukacji oferowanej dziecku, warto rozważyć, jak uczymy czytania cyfrowych tubylców w warunkach polskiego przedszkola i szkoły. Próby krytycznej rekonstrukcji tego procesu podjęłyśmy wraz z profesor Dorotą Klus-Stańską w 2005 r. ${ }^{1}$, kiedy to ukazało się pierwsze wydanie tejże książki. Wskazywałyśmy wówczas na liczne mankamenty szkolnej alfabetyzacji, przejawiające się w: niedocenianiu dziecięcych kompetencji, nierespektowaniu indywidualizacji nauki czytania i powtarzaniu podstawowego kursu kształcenia tej umiejętności, eksponowaniu ćwiczeń skoncentrowanych wyłącznie na doskonaleniu technicznej sprawności czytania, uproszczeniu i ubóstwie leksykalnym tekstów elementarzowych, a także nierozwijaniu krytyczno-twórczego kontaktu z tekstem². Zwracałyśmy również szczególną uwagę na fakt, że: „,[w] zależności od sposobu, w jaki dziecko zostaje od samego początku wprowadzone w świat pisma, będzie ono nadawało czytaniu różne

\footnotetext{
1 W 2005 r. ukazało się pierwsze wydanie Sensów i bezsensów edukacji wczesnoszkolnej w wydawnictwie WSiP w Warszawie, drugie zaś w 2009 r. również w tym wydawnictwie. Nowe, uzupełnione wydanie ukazało się w 2013 r. w Wydawnictwie Harmonia.

2 Por. rozdział „Czy szkoła rzeczywiście uczy czytać?” w przywoływanej publikacji (Klus-Stańska, Nowicka 2005: 9-42).
} 
znaczenia” (Klus-Stańska, Nowicka 2005: 21). Interesujące jest, które z formułowanych wówczas uwag pozostają aktualne w świetle współczesnej oferty podręcznikowej, powstałej w odmiennej kulturowej rzeczywistości.

Zanim przystąpię do referowania powziętych kroków badawczych, w celu lepszego zobrazowania instytucjonalnej alfabetyzacji dzieci i by poszerzyć kontekst przedstawianych w artykule rekonstrukcji, skrótowo nawiążę do znaczących posunięć reformujących czas, zakres i metody instytucjonalnej nauki czytania i pisania.

Elementarną naukę czytania zadekretowano w programie pracy dydaktyczno-wychowawczej przedszkola z dziećmi sześcioletnimi pół wieku temu i od tego czasu nastąpiło zasadnicze zbliżenie modelu pracy przedszkola i szkoły w zakresie wprowadzania dzieci w świat pisma. W 1973 r. opublikowano nowy "Program wychowania w przedszkolu” zawierający część pt. „Dojrzałość szkolna i przygotowanie dzieci do nauki w szkole” oraz powołano oddziały przedszkolne dla sześciolatków. W programie wskazano, że jednym z głównych zadań wychowania przedszkolnego jest przygotowanie dziecka do nauki czytania i pisania oraz zamieszczono treści, które miały pomóc w realizacji działań przygotowujących dziecko do roli ucznia. Dokładne wytyczenie ram pracy przedszkola w zakresie przygotowania dzieci do czytania i pisania nastąpiło w 1977 r. w związku z upowszechnieniem wychowania przedszkolnego dla wszystkich dzieci sześcioletnich. Ukazała się wówczas wkładka do wcześniejszego programu, zatytułowana: „Zakres treści wychowania i kształcenia dla dzieci sześcioletnich”. W ramach rozwijania gotowości do czytania zadaniem przedszkola było rozwijanie słuchu fonematycznego i umiejętności analizy i syntezy dźwiękowej oraz wzrokowej wyrazów. Dzieci miały być zaznajamiane $\mathrm{z}$ istotą liter jako symboli graficznych, tworzyć i czytać wyrazy o prostej budowie fonetycznej z wykorzystaniem 22 liter drukowanych małych i wielkich oraz czytać krótkie zdania i teksty. Pisanie zostało oderwane od czytania i tylko w przypadkach zainteresowania dziecka pisaniem nauczyciel miał dostarczać dziecku jego wzorów (Arciszewska 2002: 74-75). Zatem od momentu programowego wdrożenia kursu czytania do działań przedszkola i nasilenia powstawania oddziałów przedszkolnych organizowanych przy szkołach (tzw. „zerówek”) można datować proces utrwalania jednolitego toku wprowadzania liter w przedszkolu i szkole. Wzmocniony on został zaleceniem korzystania z podręcznika, którym - jak pisze Ewa Arciszewska (2002: 74) - stała się automatycznie jedyna obecna w owym czasie na rynku wydawniczym pozycja Mam 6 lat. Wyprawka dla sześciolatka Ewy i Feliksa Przyłubskich. Obowiązująca w niej analityczno-syntetyczna metoda nauki czytania o charakterze fonetycznym w odmianie wyrazowej i z elementami metod dźwiękowo-barwnych oraz tok wprowadzenia liter stały się podbudową założeń metodycznych pracy przedszkola i szkoły na następne dekady. Kolejne roczniki dzieci skazywane były na realizację oferty metodycznej opartej na założeniach reformy z 1977 r. (Arciszewska 2002: 84), choć preferowanie wzorca „szkolnego” w realizacji nauki czytania spotykało się z głosami krytyki (Jaszczyszyn 2010: 46-47). W myśl założeń programowych miał on być zróżnicowany na obu tych etapach, lecz „w efekcie podjętych w tym zakresie działań »fragmentaryczna nauka czytania« w edukacji przed- 
szkolnej została zdominowana przez szkolne metody nauczania, które zamiast radości z opanowywania umiejętności czytania przyniosły tylko nadmierną »dydaktyzację« treści kształcenia” (Kamińska 1999: 35).

Warto podkreślić, że od lat dziewięćdziesiątych można odnotować otwarcie przedszkola na alternatywne metody nauki czytania ${ }^{3}$ i proces ten, choć niepowszechnie, jest kontynuowany współcześnie. Tymczasem nauka czytania w szkole masowej jedynie wyjątkowo uwzględnia elementy różnych alternatywnych podejść, w głównym nurcie jednak jest niezmiennie skoncentrowana na wariantach metody analityczno-syntetycznej, w której analiza i synteza słuchowa wyprzedzają wzrokową ${ }^{4}$ Nawet wielość podręczników, zadekretowana reformą z 1998 r. oraz następnych reform, nie przełamała tego monopolu.

Do rozwiązania impasu upodobnienia działań przedszkola i szkoły w zakresie uczenia czytania dzieci mogła się przyczynić reforma programowa z 2009 r. Choć miała liczne mankamenty ${ }^{5}$, pozytywnie porządkowała proces alfabetyzacji, zakładając, że podstawowy kurs czytania będzie się odbywał tylko raz dla dzieci sześcioletnich w szkole. Założenia te realizowano etapowo i w konsekwencji zmiany polityki oświatowej przedsięwzięcie zostało zaniechane, bowiem w 2016 r. zniwelowano obowiązek szkolny dla sześciolatków.

Zapisy ostatniej podstawy programowej co do kształcenia umiejętności czytania w przedszkolu różnią się od wymagań zadekretowanych dla szkoły. W świetle założeń reformy okres przedszkolnej nauki czytania ma wyraźnie charakter propedeutyczny, oparty głównie na zabawie, podczas gdy w klasach wczesnoszkolnych proces ten ma sformalizowane cele, zwłaszcza jeśli chodzi o aspekt techniczny tej umiejętności. Zgodnie z podstawą programową po ukończeniu edukacji przedszkolnej dziecko „rozpoznaje litery, którymi jest zainteresowane na skutek zabawy i spontanicznych odkryć, odczytuje krótkie wyrazy utworzone $\mathrm{z}$ poznanych liter $\mathrm{w}$ formie napisów drukowanych dotyczące treści znajdujących zastosowanie w codziennej aktywności” (Rozporządzenie Ministra Edukacji Narodowej z dnia 14 lutego 2017 r. w sprawie podstawy programowej wychowania przedszkolnego oraz podstawy programowej kształcenia ogólnego dla szkoły podstawowej (...) (tekst jedn.: Dz. U. z 2017 r., poz. 356 ze zm.: 6)). Natomiast dziecko po pierwszym etapie edukacji: „1) czyta płynnie, poprawnie i wyraziście na głos teksty zbudowane z wyrazów opracowanych w toku zajęć, dotyczące rzeczywistych doświadczeń dzieci i ich oczekiwań poznawczych; 2) czyta w skupieniu po cichu teksty zapisane samodzielnie

\footnotetext{
3 Takie jak: Metoda Dobrego Startu według Marty Bogdanowicz, metoda odimienna nauki czytania Ireny Majchrzak, metoda naturalnej nauki języka według Elżbiety Czerwińskiej i Małgorzaty Narożnik, metoda fonetyczno-literowa Bronisława Rocławskiego, „Sojusz metod” według Ewy Arciszewskiej, metoda globalna według Haliny Mystkowskiej, Hanny Dobrowolskiej-Bogusławskiej, „Zabawa w czytanie” Glenna i Janet Domanów, metoda symultaniczno-sekwencyjna, tzw. krakowska, Jagody Cieszyńskiej, „Cudowne dziecko" Anety Czerskiej.

4 Anna Jurek (2012) identyfikuje w nich różnie rozłożone akcenty, dodając do podstawowej nazwy metody doprecyzowujące ją określenia, takie jak: o charakterze funkcjonalnym, dźwiękowo-barwna, wyrazowa, o charakterze fonetycznym, o charakterze fonetyczno-graficznym, z silną ekspozycją sylaby, z sylabą jako etapem pośrednim, z wyeksponowaniem relacji głoskowo-literowych.

5 Pisaliśmy o tym w specjalnym numerze „Problemów Wczesnej Edukacji” w 2009 r.
} 
w zeszycie oraz teksty drukowane" (Rozporządzenie Ministra Edukacji Narodowej 2017, poz. 356: 34). Jeśli chodzi o pisanie, to nauka tej czynności jest możliwa już w przedszkolu, w sytuacji przejawianego przez dzieci zainteresowania nauczyciel przygotowuje je „do wykonywania tychże czynności zgodnie z fizjologią i naturą pojawiania się tychże procesów” (Rozporządzenie Ministra Edukacji Narodowej 2017, poz. 356: 8).

\section{Zarys projektu badań}

Przebieg procesu alfabetyzacji dzieci w ostatniej grupie przedszkolnej i klasie pierwszej szkoły podstawowej można rekonstruować, bezpośrednio go obserwując, a także analizując podręczniki dopuszczone do nauki czytania w tych instytucjach. Dodatkowych informacji dostarczają poradniki metodyczne ukazujące zamysł autorów co do kolejnych kroków kursu czytania na danym etapie.

Celem zaprojektowanych badań było rozpoznanie, jak przebiega i czym różni się proces nauki czytania dzieci sześcioletnich i siedmioletnich w świetle aktualnych podręczników oraz przewodników metodycznych w przedszkolu i w szkole. Interesowało mnie, czy zachowana jest ciągłość procesu alfabetyzacji między grupami przedszkolnymi i w klasach początkowych. W szczególności zajmowało mnie, jaki jest układ graficzny stron do nauki czytania na poszczególnych etapach, jakie aktywności proponuje się dzieciom przy wprowadzaniu nowej litery i jakie się przewiduje ćwiczenia utrwalające. Skupiłam się również na tekstach przeznaczonych do nauki czytania i formułowanych do nich poleceniach w kontekście ich użyteczności w kształceniu aspektu technicznego, semantycznego i krytyczno-twórczego czytania.

W badaniach zastosowałam analizę dokumentów zastanych (Łuczewski, Bednarz-Łuczewska 2012) o charakterze porównawczym. Wybór materiałów do analizy rozpoczęłam od sporządzenia rankingu popularności podręczników we wszystkich olsztyńskich publicznych przedszkolach. Informacje o wykorzystywanych seriach uzyskałam ze stron internetowych prowadzonych przez przedszkola, a w przypadku ich braku - poprzez bezpośredni kontakt z nauczycielami bądź dyrektorem danej placówki. Do analizy wybrałam cztery najczęściej stosowane zestawy książek i/lub ćwiczeń. Znalazły się wśród nich dwie serie z tego samego wydawnictwa. Następnie w analogiczny sposób sporządziłam ranking dla olsztyńskich szkół podstawowych i kierując się miejscem na liście, dobrałam do podręczników z przedszkola podręczniki z tych samych wydawnictw popularne w szkole. Zależało mi na zsynchronizowaniu doboru wydawnictw w celu ustalenia, czy na poziomie jednego wydawnictwa dba się o ciągłość procesu alfabetyzacji dzieci przedszkolnych i szkolnych. Następnie w celu zrównoważenia liczby podręczników dla sześciolatków i siedmiolatków dobrałam jeszcze jedną serię materiałów dla siedmiolatków z dodatkowego wydawnictwa. Łącznie analiza dotyczy pakietów książek i ćwiczeń z czterech wydawnictw: Nowa Era (Dzieciaki w akcji-6-latki; Elementarz odkrywców-7-latki), MAC Edukacja (Odkrywam siebie oraz Nowe przygody Olka i Ady - 6-latki; Oto ja - 7-latki), 
WSiP (Plac zabaw - 6-latki; Nowi tropiciele - 7-latki), Juka (Ja i moja szkoła na nowo 7-latki). Do każdej z wymienionych serii dołączone są przewodniki metodyczne, które również poddałam analizie.

\section{Wyniki rekonstrukcji}

W pierwszym etapie analizy przyglądałam się układowi graficznemu stron podręcznikowych, na których eksponuje się nową literę do nauki czytania i do ćwiczeń w pisaniu. Zgromadzony materiał badawczy pozwolił na ustalenie, że charakterystyczne dla obu poziomów, tj. przedszkola i szkoły, jest przyjęcie jednego wzorca strony elementarzowej. Dzieci sześcioletnie poznają kolejno litery, korzystając z lustrzanie podobnych stronic elementarzowych, na których powtarza się w różnych wariantach podobny zestaw ćwiczeń. Modyfikacje zdarzają się rzadko i rzadko pojawiają się nowe atrakcyjne polecenia. Również dzieci siedmioletnie mają w swoich podręcznikach takie same karty, na których jest prezentowana nowa litera. Zatem dwukrotnie: jako sześciolatki i siedmiolatki w identyczny sposób spotykają się z alfabetem (por. il. 1,2). Trzeba zaznaczyć, że jeśli dzieci chodziły do przedszkola jako pięciolatki, to proces ten przechodzą trzykrotnie, bo dla tej grupy również przewiduje się podręczniki wdrażające do takiego samego układu zapisu i ilustracji, choć w okrojonej formie.

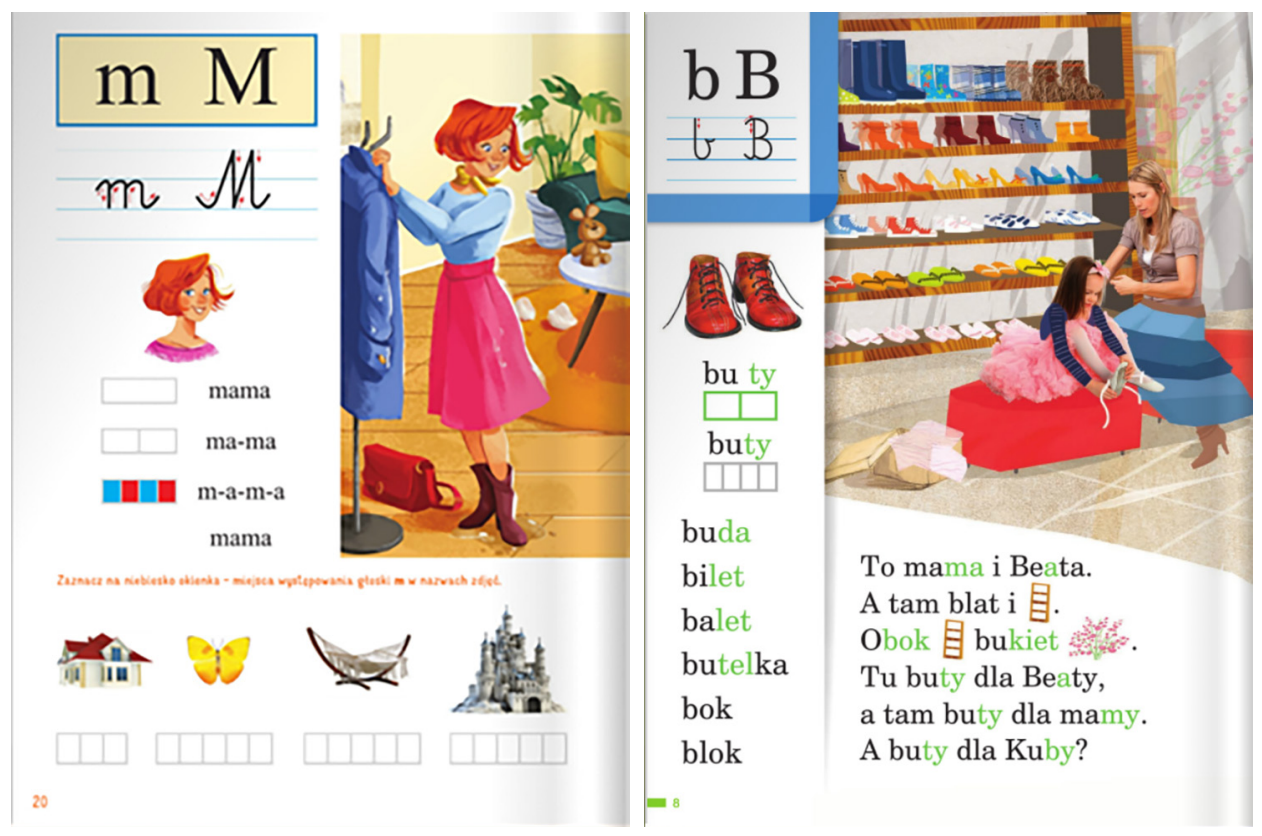

Il. 1. Nowe Przygody Olka i Ady. Litery i liczby, Il. 2. Elementarz odkrywców. Podręcznik, cz. 2 cz. 1 (litera M) (Żaba-Żabińska, Banaś 2019: 20)

(litera B) (Hryszkiewicz, Stępnień 2017: 8) 
Zarówno dla sześciolatków, jak i siedmiolatków na stronach elementarzowych podręcznika przewiduje się: obrazek do ćwiczeń w mówieniu, w którym eksponuje się desygnat wyrazu podstawowego, pokaz małej i wielkiej litery drukowanej oraz pisanej w liniaturze, schemat/model do analizy i syntezy wyrazu podstawowego (często akcentuje się sylabę), dodatkowo proponuje się ćwiczenia w analizie i syntezie słuchowej bądź wzrokowej oraz wyrazy bądź teksty do czytania. Być może w celu „urozmaicenia” tej stronicy w podręczniku szkolnym pasek z ćwiczeniami nie znajduje się z lewej strony ilustracji, ale na przykład nad nią. Karty stronic dla siedmiolatków zazwyczaj zawierają nieco dłuższe teksty lub stopniowane są poziomy ich trudności: dla dzieci słabiej czytających w krótszej, wyrazowo-obrazkowej formie i pisane większą czcionką oraz dla dzieci czytających lepiej. Zachodzi prawdopodobieństwo, że wyrazy podstawowe, służące wprowadzaniu nowej litery się powtórzą, jak chociażby w przypadku $m$ jak mama, $t$ jak tata, $k$ jak kot. Można powiedzieć, że autorzy podręczników dla siedmiolatków wykazują pewną uwagę, by wizualnie urozmaicać wzorzec strony, z jaką dzieci spotkają się w książkach w przedszkolu, jednak finalnie jej konstrukcja pozostaje wciąż ta sama.

Równolegle z nauką czytania prowadzona jest nauka pisania, zarówno w przedszkolu, jak i w szkole. I tu również mamy do czynienia z replikowaniem stron w ćwiczeniach dla sześciolatków, jak i siedmiolatków, co uwidaczniają przedstawione ilustracje 3 i 4 . Tylko po wielkości prezentowanej liniatury można rozpoznać, które z nich przeznaczone są dla młodszych dzieci, choć nawet ta cecha nie jest obserwowana w każdym z analizowanych pakietów.

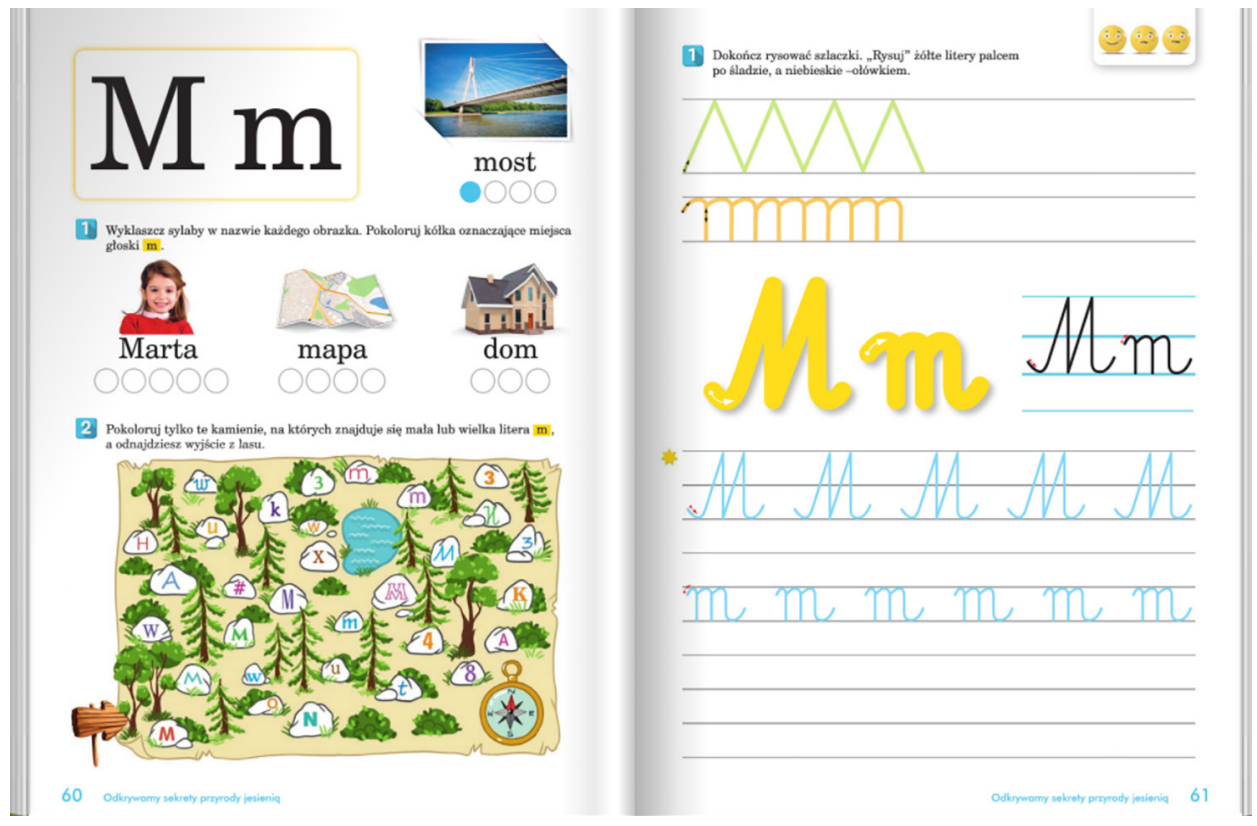

Il. 3. Dzieciaki w akcji. Karty pracy sześciolatka, cz. 1 (litera M) (Stalmach-Tkacz, Mucha 2018: 60-61) 


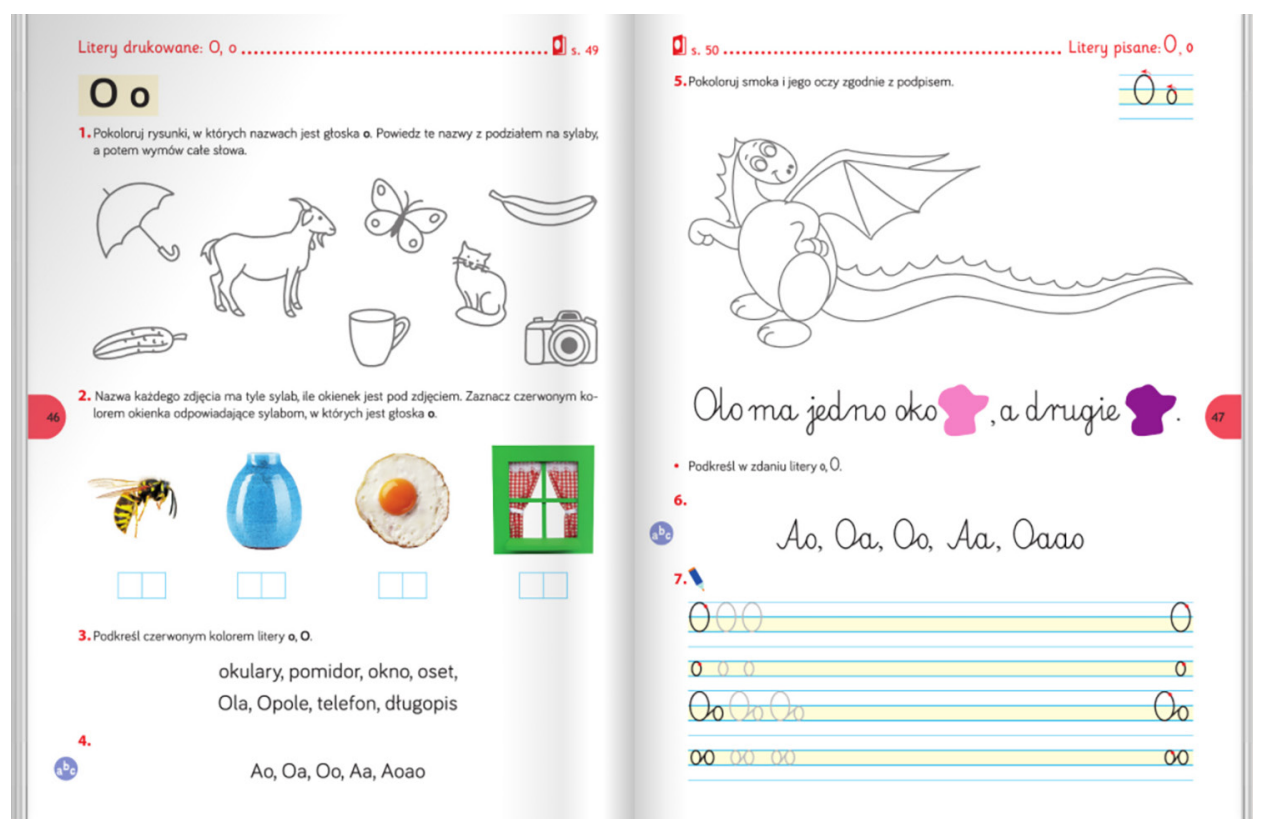

Il. 4. Ja i moja szkoła na nowo. Zeszyt ćwiczeń dla klasy 1, cz. 1 (litera O) (Faliszewska, Lech 2020: 49-50)

Oczywiście podobieństwo stronic elementarzowych do czytania i stronic do pisania w ćwiczeniach dla sześciolatków i siedmiolatków nie kończy się tylko na aspekcie graficznym. To, co dzieje się w klasie z wykorzystaniem stron elementarzowych, cementują bowiem wskazania zawarte w przewodnikach metodycznych. Są one nagminnie wykorzystywane w pracy dydaktycznej przez nauczycieli wczesnej edukacji (por. Jakubowicz-Bryx 2015: 172), dlatego na ich podstawie można antycypować przebieg instytucjonalnej alfabetyzacji. W analizowanych materiałach, zarówno dotyczących pracy w przedszkolu, jak i szkole, podaje się taki sam tok wprowadzania nowej litery. Dzieci przeprowadza się przez kolejne identyczne kroki: rozmowa tematyczna związana z desygnatem wyrazu podstawowego; analiza i synteza słuchowa oraz wzrokowa wyrazu podstawowego, wspomagana budowaniem struktury dźwiękowej wyrazu z wykorzystaniem kartoników białych lub czerwonych i niebieskich; demonstrowanie nowej litery małej i wielkiej w wersji drukowanej i pisanej i w końcu nauka pisania po śladach i samodzielnie. Szablon jest niezmienny przy każdej nowej literze, co dobitnie uwidacznia przykład ostatnich stron jednego z analizowanych przewodników, na których zamieszczono go odrębnie jako podstawowy wzór działań, dopuszczając jedynie lekkie jego modyfikacje w scenariuszach na kolejne dni planowanych zajęć (Elementarz odkrywców. Książka nauczyciela, cz. 1: 210-211). Trzeba mieć świadomość, że dzieci trenują ten „tok” przy każdej literze wprowadzanej na kartach podręcznika przedszkolnego, a potem taki sam przy każdej kolejnej literze w podręczniku w szkole. Nietrudno sobie wyobrazić, jak reagują współczesne dzieci na tę schematyczną, 
nużącą praktykę, która wystawia na ciężką próbę ich cierpliwość i motywację do podejmowania czytania w ogóle.

Na kanwie szablonu wprowadzania liter proponuje się dzieciom różne warianty ćwiczeń kształcących i utrwalających zdobyte umiejętności. Dzieci w wieku sześciu lat, a następnie jako siedmiolatki muszą obowiązkowo zaliczyć:

- wymawianie wyrazów z podziałem na głoski i sylaby;

- liczenie głosek i sylab w wyrazach (stawianie odpowiedniej liczby kresek);

- wyróżnianie kolorem samogłosek i spółgłosek w modelach wyrazów;

- podawanie wyrazów z określoną głoską w nagłosie, śródgłosie i wygłosie;

- kolorowanie nowo poznanych liter w zapisanych wyrazach lub tekstach;

- czytanie połączeń nowo poznanej spółgłoski z samogłoską;

- odszukiwanie na ilustracjach obiektów zawierających w nazwie nowo poznaną literę;

- tworzenie wyrazów z połączenia głosek w nagłosie z kilku przedstawionych na ilustracji obiektów;

- wybieranie liter z zestawu w celu utworzenia określonego wyrazu;

- kolorowanie nowo poznanej litery, odszukiwanie jej na różnych schematach, ilustracjach;

- rozwiązywanie krzyżówek, rebusów z wyrazami z nowo poznaną literą itp.

Ewentualna „zmiana”, jakiej dzieci doświadczają przy zapoznawaniu się z kolejnymi literami, to zamiana kolejności czy wariantów danego ćwiczenia. Na przykład w przedszkolu przy wprowadzaniu litery $t$ na podstawie wyrazu tata zaplanowano ćwiczenie:

Podawanie przykładów słów rozpoczynających się głoską $t$ (torba, tor, trawa...), kończących się tą głoską (drut, krawat, młot...) i mających ją w środku (mata, buty, klatka...) (Odkrywam siebie. Przewodnik metodyczny, cz. 1: 34).

W szkole, zgodnie z przewodnikiem metodycznym z tego samego wydawnictwa, dzieci również poznają małą literę $t$ na podstawie wyrazu tata i mają wykonać inny wariant tego zadania:

Dzieci w parach przygotowują kartkę z bloku i składają ją na połowę. Następnie zabierają z pudła kolorowe gazety (m.in. ulotki ze sklepów) i szukają w nich obrazków, w nazwie których na początku lub na końcu słychać głoskę t. Wycinają je i wklejają na kartkach z bloku (...) (Oto ja. Przewodnik metodyczny, cz. 1: 80).

Jest zrozumiałe, że przy zastosowaniu takiej samej metody nauki czytania w przedszkolu i szkole trudno o radykalne innowacje w zakresie doboru zadań. W jakim celu zatem w ogóle tę naukę powtarzać? Oto inne przykłady różnych wariantów tego samego ćwiczenia:

Podaj nazwy przedmiotów widocznych na zdjęciach. Otocz pętlą obrazek, w którego nazwie litera e występuje najczęściej. Podkreśl na czerwono wszystkie litery e w każdym wyrazie. Przeczytaj wyrazy. 
[poniżej ilustracje i napisy: fotel, ekran, elf, kret, serce, grabie, deska] (Plac zabaw. Sześciolatek...: 35).

Nazwij rysunki. Podziel każdy wyraz na głoski. Wklej literę a w odpowiednie miejsce modelu głoskowego pod każdą ilustracją.

Odszukaj w wyrazach litery e, E. Zaznacz je czerwoną kredką. [poniżej napisy: elf, seler, deska, worek, Edek, Europa, metro, bratek, Egipt, ser, serce, lego, kameleon, goryle, meble, fotel, ekran, elf, kret, serce, grabie, deska, deszcz] (Elementarz odkrywców. Ćwiczenia, cz. 1: 19, 26).

Konsekwentne zlecanie zadań już wcześniej wykonywanych przez dzieci wprost przeczy osiągnięciom psychologii rozwojowej, zgodnie z którą ,„[n]auczyciele muszą się nauczyć oceniać »gradienty trudności« w zadawanych dzieciom ćwiczeniach na pisanie i czytanie, aby mieć pewność, że zadanie dostarcza dziecku wystarczającego wyzwania, pozwalającego na dokonanie postępu (...)” (Wood 2006: 264). „Kompulsywne” powtarzanie tych samych sytuacji ćwiczeniowych to przejaw blokowania i marnowania potencjału rozwojowego dzieci przez szkołę. Dzieci przestają mieć zaufanie do własnych kompetencji i poddawane treningowi podporządkowania nauczycielowi rozwijają różne strategie przetrwania $\mathrm{w}$ instytucji oderwanej od ich rzeczywistych potrzeb. Nie należy mieć złudzeń, że doświadczenia szkolne zatrą się i nie wpłyną trwale na uczniów, bowiem jak podkreśla Jerome Bruner: „,[e]dukacja, realizowana w dowolny sposób w dowolnej kulturze, zawsze ma konsekwencje w późniejszym życiu tych, którzy przez nią przechodzą" (2006: 45).

W opisanym ogromnym nasyceniu podręczników ćwiczeniami w analizie i syntezie słuchowo-wzrokowej przejawia się silna koncentracja na aspekcie technicznym czytania. Zerwanie ciągłości kursu czytania pomiędzy przedszkolem i szkołą powoduje, że dzieciom siedmioletnim w szkole wmawia się, że poznają nowe litery. W każdym z przewodników metodycznych dla klasy pierwszej, przy każdej kolejnej literze jest mowa o jej „poznawaniu”, „wprowadzaniu” i o tym, że jest ona „nowo poznana”, np.:

Wprowadzanie drukowanych liter a, A na podstawie wyrazów album i Ada. Nauka pisania liter a, A (Elementarz odkrywców. Książka nauczyciela, cz. 1: 68).

Na poprzednich zajęciach poznaliście drukowane litery K, k. Potraficie je rozpoznawać wśród innych znanych liter (...). Czytaliście sylaby i wyrazy z nowo poznaną literą (...). $\mathrm{Na}$ dzisiejszych zajęciach poznacie kształt pisanych liter K, k. Będziecie je pisać po śladach i samodzielnie (Oto ja. Przewodnik metodyczny, cz. 2: 71).

Oczywiście podobne zapisy znajdziemy w przewodnikach metodycznych dla dzieci młodszych, sześcioletnich: 
Zabawy i ćwiczenia z literą m. Cel: zapoznanie z literą m: małą i wielką, drukowaną (5-latki) i pisaną, utrwalenie pojęcia spółgłoska (6-latki) (Odkrywam siebie. Litery i liczby, cz. 1: 138).

Kolorowanie na niebiesko liter d, D w wyrazach. Czytanie sylab, wyrazów, zdań. Rozwiązywanie rebusów. Łączenie tych samych liter pisanych z drukowanymi. Wodzenie palcem po literze d-małej i wielkiej. Pisanie liter d, D po śladach, a potem samodzielnie (Nowe przygody Olka i Ady. Przewodnik metodyczny, cz. 2: 61).

Ze wskazań metodycznych w przewodnikach wynika, że już dzieci pięcioletnie wprowadza się w świat pisma, pokazując im litery drukowane. Dzieci sześcioletnie poznają litery drukowane i pisane, rozróżniają pojęcia głoska, samogłoska, spółgłoska, litera, sylaba, wyraz, zdanie. Sześciolatki również już piszą nowo poznane litery. Tymczasem przewodniki dla nauczycieli klasy pierwszej pomijają niejako zapisy z wcześniejszych etapów i nie nawiązuje się w nich do umiejętności dzieci nabytych w przedszkolu. Dobitnie świadczy o tym następujący zapis z poradnika metodycznego dla klasy pierwszej:

Dzieci przygotowują zieloną kredkę i ołówek. Szukają w wierszyku liter K, k i podkreślają je kredką. Szukają innych liter, które poznały do tej pory, i podkreślają je ołówkiem (Oto ja. Przewodnik metodyczny, cz. 2: 70).

Oczywiście, pisząc o ,poznanych do tej pory” literach, autorzy poradnika mają na myśli wyłącznie te litery, które do tego czasu wystąpiły w podręczniku (por. Oto ja. Przewodnik metodyczny, cz. 2: 68). Zapisowi w przewodniku odpowiada następujące ćwiczenie w zeszycie ćwiczeń:

Znajdź w wierszyku litery K, k. Podkreśl je zieloną kredką. Poszukaj innych liter, które już znasz. Podkreśl je ołówkiem.

Rzekł [K jest podkreślone na wzór - przyp. M.N.] do króla kucharz Kacper:

- Królu! Mam to wszystko w nosie!

Rzucił króla, kuchnię, zamek

I zamieszkał w Kampinosie (Oto ja. Ćwiczenia polonistyczno-społeczne, cz. 1: 51).

Jak uwidoczniają to przytoczone przykłady, w szkole nauczyciel ma się zachowywać tak, jakby odkrywał przed dziećmi świat nigdzie i nigdy niewidzianych tajemniczych znaków. Dowodzi to, że autorzy podręczników i poradników nie mają podstawowej orientacji w badaniach nad współczesnym dzieciństwem i kompetencjami dzieci.

Nadmierna ekspozycja aspektu technicznego czytania wyraża się również w rodzaju działań, które wyznaczają autorzy materiałów dla siedmiolatków:

Przeczytaj tekst najładniej, jak potrafisz (Elementarz odkrywców. Podręcznik, cz. 2: 36).

Naucz się czytać i pisać litery O, o (Ja i moja szkoła na nowo. Podręcznik, cz. 1: 50). 
Poleceniami odnoszącymi się do doskonalenia techniki czytania są bardzo nasycone tzw. elementarzowe strony podręczników ze specjalnie spreparowanymi tekstami do czytania przez uczniów. Ostatni z zaprezentowanych przykładów szczególnie zadziwia w kontekście całorocznej nauki dziecka w przedszkolu.

Nadmierna instrumentalizacja wczesnej alfabetyzacji przejawia się także w koncentracji na czytaniu sylab, nic nieznaczących zbitek literowych oraz zestawionych przypadkowo wyrazów. Takie ćwiczenia pojawiają się przy każdej nowo wprowadzanej literze, np.:

Czytaj z Erykiem sylaby zapisane w wagonikach pociągu - raz szybko, raz wolno:

te le de me ke pe et el tek tel kle (Oto ja. Podręcznik polonistyczno-społeczny, cz. 1: 54).

Przeczytaj.

ete iti ata mata tama tam meta temat (Nowe przygody Olka i Ady. Litery i liczby, cz. 1: 37).

Koncentracja na aspekcie technicznym czytania nie ma w świetle analizowanych podręczników charakteru rozwiązywania problemów (Konior-Węgrzynowa 2015). Nie daje się dzieciom szansy na wniesienie własnego wkładu w czynność czytania i wykorzystywania dziecięcych intuicji dotyczących tego procesu. Ważne byłoby np. uczenie zadawania sobie samemu pytań o poprawność przeczytanego tekstu i zachęcanie do przewidywania (stawiania hipotez), jak powinien działać. Pytania o istotę czytanych treści (np. Co tu może mieć sens? Co może brzmieć poprawnie?) powinny wyprzedzać pytania dotyczące kodu (np. złóż głoski/sylaby?) (Konior-Węgrzynowa 2015: 62 i nn.). Nadmierna koncentracja na technice czytania i oddalenie treningu krytyczno-twórczej relacji z tekstem zatrzymuje dzieci niejako wpół drogi do nabywania pełnych kompetencji czytelniczych. Wpędza je w kłopoty z czytaniem, o których pisze David Wood (2006: 202). Jego zdaniem wielu, również starszych, uczniów ma trudności, bowiem nie doświadczyło w procesie nauki czytania aktywnej interakcji z tekstem, polegającej na podejmowaniu prób interpretacji tego, co się czyta. Ważne jest, by organizować sytuacje samodzielnego i we współpracy z innymi dziećmi zadawania pytań istotnych dla zrozumienia tekstu, spekulowania na temat możliwego rozwoju wydarzeń czy zastanawiania się nad niejasnymi fragmentami. Takie działania znacząco poprawiają wyniki testowe umiejętności czytania, a także ogólne wyniki szkolne (Wood 2006: 203).

Kolejny etap przeprowadzanej przeze mnie rekonstrukcji dotyczył jakości tekstów prezentowanych w podręcznikach. Podczas analizy zgromadzonych materiałów uwidoczniła się ograniczoność ich rodzajów i form. Do czytania samodzielnego uczniów przewiduje się głównie czytanki zaprezentowane w statycznej formie, jak w następującym przykładzie:

Mama lubi irysy.

One urosną wiosną.

Mati lubi Indian.

To dlatego ma na głowie pióra (Nowi tropiciele. Podręcznik, cz. 1: 42). 
Ponadto, jak wynika z rekonstrukcji, do tekstów, które dzieci mają czytać samodzielnie, nie stosuje się pytań krytyczno-twórczych. Mają one głównie sprawdzać rozumienie tekstu na poziomie technicznym i podstawowym semantycznym.

Przeczytaj tekst. Odszukaj w nim wyrazy, w których występuje h, H, a następnie wyrazy z ch. Odczytaj je.

Odszukaj w tekście zdanie mówiące o tym, kiedy poznamy odgłosy natury. Przeczytaj to zdanie. (Elementarz odkrywców. Podręcznik, cz. 3: 35).

Poprzez takie pytania i ukierunkowanie głównie na odkodowania podstawowych znaczeń, jakie generuje tekst, utrwala się pasywną kulturę czytelniczą. Przypisywanie czytankom zamieszczanym w podręcznikach szkolnych tylko funkcji służebnej w stosunku do celów dydaktycznych uniemożliwia kształtowanie refleksyjnego kontaktu z tekstem (Zabawa 2012: 162).

Dodatkowo, jeśli chodzi o poruszaną tekstach czytankowych problematykę, to jest ona mało ciekawa i brak w niej walorów poznawczych. Interesujące treści pojawiają się, gdy ma je czytać nauczyciel, a dzieci tylko uważnie odsłuchać. Ponadto dodatkowe teksty do czytania, zamieszczane przez niektóre wydawnictwa jako „poczytanki” do doskonalenia nauki czytania, trudno uznać za interesujące dla dzieci. Oto przykład:

To Cela i Wacek. A to mama Celi - Cecylia. I tata Celi - Maciej. Mama Celi to ciocia Wacka, a tata Celi to wujek Wacka. Cecylia kupiła Celi i Wackowi klocki, a Maciej upiekł im kakaowe ciastka. Cela i Wacek układają z klocków ulicę. Tam jadą motocykle. Koło ulicy stoi pajac Lucek (Oto ja. Czytam-zeszyt ćwiczeń: 27).

Motywację dzieci do czytania znacznie obniża fakt, że ilustracje wiernie odzwierciedlają to, co jest przedstawione w tekście. W przewodnikach na ogół zaleca się uprzednie przeprowadzenie rozmowy dotyczącej omówienia ilustracji, z tego powodu odczytywanie treści w ogóle mija się z celem (Elementarz odkrywców. Książka nauczyciela, cz. 1: 153).

Mankamentem obniżającym dziecięcą motywację może być również powtarzalność problematyki omawianej przy prezentacji liter w przedszkolu i szkole. Zarówno dzieci sześcio-, jak i siedmioletnie przy poznawaniu nowych liter rozmawiają o darach jesieni i swoich ulubionych zabawkach, poznają zwierzęta domowe i owady, odbywają wizyty na wiejskich podwórkach, rozmawiają o mamie i tacie oraz o ulubionych postaciach z bajek itd. To nic, że kanwa rozmowy służy wprowadzeniu innej litery, jednak jej wartość poznawcza zawsze będzie zbliżona, bo podobne będą pytania. Na przykład odnośnie do wprowadzenia litery $E, e \mathrm{w}$ jednym z podręczników proponuje się:

Jakie kolory mają liście drzew jesienią? (...)

Jakie drzewa liściaste przedstawione są na ilustracji?

Odszukaj na ilustracji owoce tych drzew i podaj ich nazwy. 
Jak przygotowują się do zimy zwierzęta przedstawione na ilustracji?

Jaka pogoda przedstawiona jest na ilustracji (...) (Ja i moja szkoła na nowo. Podręcznik, cz. 1: 66).

Podobne pytania wybrzmią w przedszkolu przy ,wprowadzeniu schematu dźwiękowego jako ilościowego oznaczania głosek" (Nowe przygody Olka i Ady. Przewodnik metodyczny, cz. 1: 68), przy okazji przewiduje się: „Oglądanie zdjęcia kasztanowca w poszczególnych porach roku. Określanie różnic pomiędzy drzewami (...)”, a zgodnie z celami operacyjnymi dziecko „wymienia oznaki jesieni, (...) wymienia kolory spotykane w przyrodzie jesienią" i na podstawie zabawy badawczej dowie się, „dlaczego drzewa tracą liście” (Nowe przygody Olka i Ady. Przewodnik metodyczny, cz. 1: 68-69).

Infantylizacja i wąski zakres tematyczny tekstów podręcznikowych stanowią ogromny mankament wczesnoszkolnej edukacji dziecka (Klus-Stańska 2004a; Michalak 2011; Wiśniewska-Kin 2013; Zalewska 2013). Czytanie prostych, banalnych tekstów o powtarzającej się problematyce, opatrzonych w dodatku stereotypowymi poleceniami nie tylko nie przynosi dzieciom żadnych korzyści, ale skutecznie legitymizuje sprawowanie władzy nad dziecięcymi znaczeniami (Klus-Stańska 2004b: 35). Świat podręczników szkolnych zostaje przez to zdekontekstualizowany i temporalnie przesunięty w stosunku do świata współczesnego dziecka (Zalewska 2013: 294), a narzucanie znaczeń ,zamyka dzieci, odgradza je, odbiera im motywację do wysiłku towarzyszącego odkrywczości, niweczy szansę wzbogacania obrazu samego siebie dzięki satysfakcji płynącej z zajmowania się sprawami poważnymi i istotnymi” (Wiśniewska-Kin 2013: 333).

Przeprowadzony ogląd tekstów do nauki czytania ujawnił również zbliżone poziomy trudności technicznej czytanek w przedszkolu i szkole. Oto przykłady zapisów powiązanych z ilustracjami przy wprowadzeniu litery $c$ i $C$ dla dzieci sześcioletnich, a poniżej dla siedmiolatków:

Co to? Tata kroi 2 cebule. Olek kroi pomidory.

A to co? To cytryny. Cytryny, cebule - to same witaminy. A co robi Ada?

(Nowe przygody Olka i Ady. Litery i liczby, cz. 2: 41)

Co to? To cukier. A to? To cukierki. Ada lubi cukierki cytrynowe. Olek lubi cukierki karmelowe. Tata i mama - o smaku malinowym. A ty? Wiemy o tym - cukierki to nie witaminy. (Nowe przygody Olka i Ady. Litery i liczby, cz. 2: 42)

Mama ma dla Cecylki malutkie cudaki.

- Cecylko, to Lucek i Mucek. Lucek ma kolce, a Mucek ma macki.

- A to co, mamo?

- Kucyk!

- Mamo, ale to cudo!

Cecylka lubi takie cacka (Elementarz odkrywców. Podręcznik, cz. 2: 13). 
Jak uwidaczniają przykłady, poziom trudności obu tekstów do czytania przeznaczonych dla sześciolatków i siedmiolatków jest porównywalny. Warto zaznaczyć, że w przypadku podręcznika dla siedmiolatków przytoczono tylko jeden z dwóch zamieszczonych tam tekstów, pomijając łatwiejszy wyrazowo-obrazkowy, napisany większą czcionką.

Przedstawiona specyfika formalnej nauki czytania wpływa na fakt, że przestaje się ona kojarzyć dzieciom z działaniem mającym sens i wartym większych starań. W konsekwencji obniża się dziecięca motywacja do czytania i uczenia się w ogóle. Tymczasem dbałość o podtrzymywanie dziecięcego zainteresowania tekstem jest kluczowe dla powodzenia nauki czytania. Wiedzą o tym dobrze wydawcy książek dla najmłodszych, zaspokajając wszystkie potrzeby rozwojowe młodszego odbiorcy, a przy tym przekraczając dotychczasowe granice rozumienia procesu czytelnictwa. Dzieciom proponuje się książki partycypacyjne (participation books), które zawierają teksty zachęcające do podejmowania różnorodnych sugerowanych w nim działań (Centner-Guz 2017: 8). Nawet najmłodszych odbiorców pobudza się do aktywności werbalnej, plastycznej, manipulacyjnej czy ruchowej. Starsze dzieci zachęca się do współtworzenia książki przez podejmowanie prób pisania różnego typu tekstów. Takie interaktywne zadania odkrywają niejako przed dzieckiem tajniki powstawania książek, ze stroną graficzną włącznie (Centner-Guz 2017: 93-98). Jeśli chodzi o działania w szkole, to na interesujące podejście do początkowej nauki czytania i pisania w ramach tzw. ,alfabetyzacji motywacyjnej” wskazuje Jere Brophy (2002). Pracujący w tym programie nauczyciele stosowali zadania otwarte, wymagające interakcji rówieśniczych. Dzieci miały na przykład układać w sensownym porządku pocięte przez nauczyciela fragmenty rymowanek. Musiały przy tym posługiwać się wieloma strategiami: planować działania, wypróbować różny układ wyrazów, sprawdzać sens układu, brać pod uwagę litery duże i małe, przestrzegać interpunkcji itp. Inne dzieci, w ramach całotygodniowych obchodów urodzin ulubionego bohatera z lektury, wykonywały różne zadania, które mogły sobie wybrać z określonej przez nauczyciela puli. Mogły pisać o przyjęciu przedstawionym w książce, sporządzać listę spraw do załatwienia, przygotować przywieszki do prezentów, czytać inne książki o tym bohaterze itp. Jeszcze inny przykład działań w ramach alfabetyzacji motywacyjnej dotyczył zachęcania dzieci do wyboru interesujących dla nich książek do sesji czytania na głos, a kolejny wskazywał na możliwość komponowania tekstów na ten sam temat, ale ujęty w różnych możliwych wariantach kontekstowych. Jak podkreśla Brophy (2002: 150-152), ćwiczenia w ramach alfabetyzacji motywacyjnej, wiążące czytanie z działaniem, ukierunkowane są na wyzwalanie samodoskonalenia i realizacji zainteresowań, wzmacniają autonomię i skłaniają do rówieśniczego współdziałania. Niestety w analizowanych podręcznikach teksty do nauki czytania nie zawierają tego typu zadań. Oto dodatkowy przykład:

Przyjrzyj się ilustracji. Powiedz, co robią Ela i jej tata.

Kim z zawodu jest tata Eli?

Wyszukaj na ilustracji przedmioty, w których nazwach słyszysz głoskę $l$.

Wskaż w tekście wyrazy z literą L. 
Wymień przedmioty, które znajdują się w pracowni artysty malarza.

Co najchętniej malujesz i jakich farb najczęściej używasz?

(Nowi Tropiciele. Podręcznik, cz. 2: 22-23)

\section{Podsumowanie}

Przedstawione wyniki analizy, mimo że nie dotyczą wszystkich serii zadekretowanych przez Ministerstwo do użytku szkolnego, dają orientacyjny wgląd w proponowane dzieciom sytuacje uczenia się czytania na poziomie przedszkola i szkoły. Przebieg podstawowego kursu czytania dla sześcio- i siedmiolatków charakteryzuje się cechami, które można podsumować w następujących punktach:

1. Klonowanie strony elementarzowej i ćwiczeniowej na poziomie tej samej grupy wiekowej i między poziomami przedszkola i szkoły - ten sam układ stron elementarzowych, identyczny tok wprowadzania nowej litery i ćwiczenia w analizie i syntezie wzrokowo-słuchowej wyrazów.

2. Koncentracja na aspekcie technicznym czytania - skupienie na puli znanych liter, mocne akcentowanie czytania sylab, czytanie nic nieznaczących połączeń literowych.

3. Ograniczoność merytoryczna materiałów i tekstów do czytania - ograniczanie rodzajów i form tekstów oraz ich problematyki.

Wyniki analizy podręczników dla sześcio- i siedmiolatków wskazują, że właściwa nauka czytania dzieci odbywa się w przedszkolu, natomiast w szkole inercyjnie powtarza się ten proces, reprodukując stosowane w przedszkolu ćwiczenia. Obecna od półwiecza zaburzona ciągłość edukacyjna między przedszkolem i szkołą rozkwita. Kolejne roczniki wprawnie czytających siedmiolatków nadal skazywane są na wielomiesięczne dreptanie w miejscu i wykonywanie zadań, które już od dawna należały do sfery ich aktualnego rozwoju. Dzieje się tak, pomimo że w naszym kraju wszystkie dzieci w wieku sześciu lat obowiązkowo odbywają roczne przygotowanie przedszkolne ${ }^{6}$, co gwarantuje, że zostały one objęte procesem alfabetyzacji. Co więcej, nawet już dzieci pięcioletnie dysponują znaczną wiedzą na temat pisma. W świetle eksploracji Anny Jakubowicz-Bryx (2015: 167) 1/3 pięciolatków podejmuje próby czytania, bo zna niektóre litery. Natomiast w przypadku dzieci sześcioletnich Grażyna Krasowicz-Kupis (2006: 16) w swoich wynikach badań wykazała, że ponad 50\% dzieci zna więcej liter, niż przewiduje program przedszkola (23 litery), a 18\% rozpoznaje poprawnie wszystkie litery alfabetu. Tylko 10\% sześciolatków rozpoznaje 10 lub mniej liter (Krasowicz-Kupis 2006: 16), a 1\% na nie zna liter i łączy się to $\mathrm{z}$ ich niskim poziomem rozwoju umysłowego (Krasowicz-Kupis 2006: 17). Poza tym - jak podkreśla Krasowicz-Kupis - „,nie ma prostej zależności między liczbą poprawnie rozpoznanych liter a wzrostem efektywności czytania" (2006: 20), bowiem w czytaniu ważne są również inne sprawności, a dzieci kompensują

6 Zgodnie z art. 31 ust. 1 Ustawy z dnia 14 grudnia 2016 r. Prawo oświatowe (tekst jedn.: Dz. U. z 2020 r., poz. $910 \mathrm{ze} \mathrm{zm}$.) sześciolatki mają obowiązek odbyć to przygotowanie w przedszkolu, oddziale przedszkolnym organizowanym w szkole lub w innej formie wychowania przedszkolnego. 
sobie niewielkie braki, korzystając z kontekstu (Krasowicz-Kupis 2006: 20). Trudno racjonalnie wyjaśnić więc, z jakiego powodu dubluje się zatem podstawowy kurs czytania. Co gorsza, owo dublowanie przeprowadzane jest według takiego samego schematu w przedszkolu i w szkole. Stereotypowe rytuały metodyczne, z którymi dzieci mają już do czynienia w przedszkolu, z jeszcze większą uciążliwością osaczają uczniów w klasie pierwszej. W świetle treści podręczników wszystkie polskie siedmiolatki, czy zdolne czy też nie, niejako „repetują klasę”, bo w ten sam sposób uczą się tego samego od początku. Zatem potencjał rozwojowy dzieci siedmioletnich w zakresie nabywania kompetencji w czytaniu jest przez szkołę nie tylko niewykorzystany, ale po prostu zaprzepaszczany, marnowany. Sytuację tę można określić pedagogicznym skandalem, zalegalizowanym przez Ministerstwo, które przecież dopuszcza podręczniki do użytku szkolnego. W świetle zaprezentowanych tu analiz nauka czytania w polskiej szkole jawi się jako zmowa dorosłych, by przedstawić dzieciom tę umiejętność jako wysoce skomplikowaną i trudną do opanowania. Ćwiczenia w podręcznikach, szczególnie na poziomie szkolnym, ograniczają sprawstwo i podważają dziecięcą wiarę we własne kompetencje. Dzieci wdraża się do działań pozorowanych, niezrozumiałych i nieprzydatnych poza szkołą. Wiejąca z tekstów nuda blokuje naturalną ciekawość poznawczą dzieci i uśmierca motywację do nauki. Koncentracja na technice uczy pasywnego kontaktu z tekstem i utrudnia nabywanie pełnych kompetencji czytelniczych. Działania te niewątpliwie dobrze służą formatowaniu dzieci i wdrażaniu do szkolnego drylu, ale z pewnością nie odpowiadają potrzebom współczesnych uczniów, zanurzonych w dynamicznie zmieniającym się i zmediatyzowanym świecie.

Niezwykle wymowny pozostaje w tym kontekście fakt, że wszystkie przedstawione mankamenty współczesnego kursu alfabetyzacji dzieci zidentyfikowałyśmy już wcześniej i dokładnie omówiłyśmy z profesor D. Klus-Stańską w książce Sensy i bezsensy edukacji wczesnoszkolnej, wydanej 16 lat temu. Już wówczas pisałyśmy o literach, które dzieci dawno znają, ale w szkole ,z panią nie poznały”, o praktykach uczenia czytania ,po szkolnemu” i „,czytania dla czytania”, prowadzących do sytuacji, „w której w umyśle ucznia utrwalają się dwa podstawowe (i często jedyne) pseudosensy nauki czytania: czyta się po to, żeby "przeczytać ładnie« i po to, by - również »ładnie« - »odpowiedzieć na pytania nauczycielki«. Dzieci przestają dostrzegać, że człowiek czyta po to, by zrozumieć, co tam jest napisane, zrozumieć w sensie dużo głębszym niż na poziomie słownikowej treści wyrazów. Może to powodować obniżenie zdolności do intelektualnego i przeżyciowego dekodowania znaczeń pisanych" (Klus-Stańska, Nowicka 2005: 40). Wskazywałyśmy w związku z tym na pilną konieczność wprowadzenia gruntownych zmian podejścia do rozwijania kompetencji czytelniczych dzieci w szkole, by zapobiec szkodom, jakie wyrządza instrumentalna metodyka. Niestety, współcześnie nasze uwagi nic nie tracą na swej aktualności, bo mimo upływu czasu i kolejnych reform programowych brak zmian w tym zakresie. Zaprezentowany raport niejako tylko „odświeża”, aktualizuje przywoływane wówczas przykłady. Jednocześnie jednak raport ten ma swój dramatycznie smutny wydźwięk. Otóż potwierdza on siłę i niepodważalność stereotypowego myślenia i projek- 
towania wczesnej edukacji dziecka, bezwzględnie pomijającego troskę o jego rzeczywisty rozwój. Autorzy podręczników i wydawcy konsekwentnie nie respektują doniesień naukowych, trzymając się inercyjnie tradycyjnych, nieadekwatnych rozwojowo i kulturowo rozwiązań. Czy jest właściwe w tej sytuacji zrzucanie całej odpowiedzialności za alfabetyzację dzieci na nauczycieli? Jak wspomóc i skłonić pedagogów do uwalniania się od toksycznego przywiązania do oferowanych na rynku wydawnictw szkolnych materiałów, które ograniczają ich samodzielność i decyzyjność w zakresie proponowanej dzieciom nauki czytania?

\section{Literatura}

Arciszewska E. (2002), Czytajace przedszkolaki. Mit czy norma? Warszawa, Wydawnictwo Akademickie „Żak”.

Batorski D. (2017), Dzieci z sieci-dostęp i korzystanie z internetu przez dzieci w wieku przedszkolnym. W: J. Pyżalski (red.), Małe dzieci w świecie technologii informacyjno-komunikacyjnych. Pomiędzy utopijnymi szansami a przesadzonymi zagrożeniami. Łódź, Wydawnictwo „Eter”.

Bąk A. (2015), Korzystanie z urządzeń mobilnych przez małe dzieci w Polsce. Wyniki badań ilościowych. Warszawa, Fundacja „Dzieci Niczyje”.

Brophy J. (2002), Motywowanie uczniów do nauki. Warszawa, Wydawnictwo Naukowe PWN.

Bruner J. (2006), Kultura edukacji. Kraków, UNIVERSITAS.

Centner-Guz M. (2017), U progu czytelnictwa. Zainteresowania książka i przygotowanie czytelnicze dzieci sześcioletnich w ujęciu temporalnym. Lublin, Wydawnictwo Uniwersytetu Marii Curie-Skłodowskiej.

Filipak E., Lemańska-Lewandowska E. (red.) (2015), Model nauczania rozwijajacego we wczesnej edukacji ucznia wedtug Lwa S. Wygotskiego. Bydgoszcz, ArtStudio.

Jakubowicz-Bryx A. (2015), Świadomość pisma u dzieci pięcioletnich. Bydgoszcz, Wydawnictwo Uniwersytetu Kazimierza Wielkiego.

Jaszczyszyn E. (2010), Modele edukacji czytelniczej w przedszkolu a gotowość do czytania i umiejętności czytania dzieci sześcioletnich. Białystok, Trans Humana.

Jurek A. (2012), Metody nauki czytani i pisania z perspektywy trudności uczniów. Gdańsk, Harmonia. Kamińska K. (1999), Nauka czytania dzieci w wieku przedszkolnym. Warszawa, WSiP.

Klichowski M., Pyżalski J., Kuszak K., Klichowska A. (2017), Jak technologie informacyjno-komunikacyjne moga wspierać rozwój dziecka w wieku przedszkolnym? - studium teoretyczne.

W: J. Pyżalski (red.), Małe dzieci w świecie technologii informacyjno-komunikacyjnych. Pomiędzy utopijnymi szansami a przesadzonymi zagrożeniami. Łódź, Wydawnictwo „Eter”.

Klus-Stańska D. (2004a), Światy dziecięcych znaczeń - poszukiwanie kontekstów teoretycznych. W: taż (red.), Światy dziecięcych znaczeń. Warszawa, Wydawnictwo Akademickie „Żak”.

Klus-Stańska D. (2004b), Treści wychowawcze w nauczaniu początkowym - edukacja pozorów. W: A. Klim-Klimaszewska (red.), Mity dzieciństwa - dramaty socjalizacji. Siedlce, Wydawnictwo AP.

Klus-Stańska D., Nowicka M. (2005), Sensy i bezsensy edukacji wczesnoszkolnej. Warszawa, WSiP. Klus-Stańska D., Nowicka M. (2013), Sensy i bezsensy edukacji wczesnoszkolnej. Gdańsk, Harmonia. 
Konior-Węgrzynowa H. (2014), Uczę czytać. Poradnik dla nauczycieli i rodziców początkujacych czytelników. Gdańsk, Harmonia.

Krasowicz-Kupis G. (2006), Rozwój i ocena umiejętności czytania dzieci sześcioletnich. Warszawa, Centrum Metodyczne Pomocy Psychologiczno-Pedagogicznej.

Łuczewski M., Bedanrz-Łuczewska P. (2012), Analiza dokumentów zastanych. W: D. Jemielniak (red.), Badania jakościowe. Metody i narzędzia. T. 2. Warszawa, Wydawnictwo Naukowe PWN.

McCrindle M., Ashley F. (2020), Undestanding Generation Alpha. Norwest NSW, McCrindle Research Pty Ltd.

Michalak R. (2011), Program nauczania w szkolnej rzeczywistości elementarnej. W: H. Sowińska (red.), Dziecko w szkolnej rzeczywistości. Założony a rzeczywisty obraz edukacji elementarnej. Poznań, Wydawnictwo Uniwersytetu im. Adama Mickiewicza.

Program wychowania w przedszkolu, wprowadzony decyzją Ministra Oświaty i Wychowania z dnia 11 maja 1973 r. (nr KO-410-3/73), wydanie broszurowe.

Wiśniewska-Kin M. (2013), Dominacja a wyzwolenie. Wczesnoszkolny dyskurs podręcznikowy i dziecięcy. Łódź, Wydawnictwo Uniwersytetu Łódzkiego.

Wood D. (2006), Jak dzieci ucza się i myśla. Kraków, Wydawnictwo Uniwersytetu Jagiellońskiego.

Zabawa K. (2012), Wspótczesna literatura dziecięca w edukacji wczesnoszkolnej - rzeczywistość i perspektywy. W: B. Surma (red.), Nowe wyzwania i perspektywy dla wychowania przedszkolnego i edukacji wczesnoszkolnej. Kraków, Akademia Ignatianum, Wydawnictwo WAM.

Zakres treści wychowania i ksztatcenia dla dzieci sześcioletnich (1977). Warszawa, Instytut Programów Szkolnych WSiP.

Zalewska E. (2013), Obraz świata w podręcznikach szkolnych dla klas początkowych. Gdańsk, Wydawnictwo Uniwersytetu Gdańskiego.

\section{Akty prawne}

Rozporządzenie Ministra Edukacji Narodowej z dnia 14 lutego 2017 r. w sprawie podstawy programowej wychowania przedszkolnego oraz podstawy programowej kształcenia ogólnego dla szkoły podstawowej, w tym dla uczniów z niepełnosprawnością intelektualną w stopniu umiarkowanym lub znacznym, kształcenia ogólnego dla branżowej szkoły I stopnia, kształcenia ogólnego dla szkoły specjalnej przysposabiającej do pracy oraz kształcenia ogólnego dla szkoły policealnej (tekst jedn.: Dz. U. z 2017 r., poz. 356 ze zm.).

Ustawa z dnia 14 grudnia 2016 r. Prawo oświatowe (tekst jedn.: Dz. U. z 2020 r., poz. 910 ze zm.).

\section{Podręczniki i przewodniki metodyczne przytaczane w tekście}

\section{Nowa Era}

Bobińska i in. (2017), Elementarz odkrywców. Książka nauczyciela. Klasa 1, cz. 1. Warszawa, Nowa Era.

Hryszkiewicz E., Stępnień B. (2017), Elementarz odkrywców. Ćwiczenia/edukacja polonistyczna, przyrodnicza, społeczna. Klasa 1, cz. 1-3. Warszawa, Nowa Era.

Stalmach-Tkacz A., Mucha K. (2018), Dzieciaki w akcji. Karty pracy sześciolatka. Cz. 1. Warszawa, Nowa Era. 


\section{MAC Edukacja}

Czarnowska-Mazurek M., Dulemba E. (2020), Oto ja. Czytam - zeszyt ćwiczeń. Klasa 1. Kielce, MAC Edukacja.

Kotulska B., Kornecka I., Kolasińska M. (2020), Oto ja. Przewodnik metodyczny. Klasa 1, cz. 1, 2. Kielce, MAC Edukacja.

Mucha K., Stalmach-Tkacz A., Wosianek J. (2017), Oto ja. Ćwiczenia polonistyczno-społeczne. Klasa 1, cz. 1, 2. Kielce, MAC Edukacja.

Żaba-Żabińska W. (2019), Nowe przygody Olka i Ady. Przewodnik metodyczny. Cz. 1, 2. Kielce, MAC Edukacja.

Żaba-Żabińska W. (2020), Odkrywam siebie. Litery i liczby. BB+. Kielce, MAC Edukacja.

Żaba-Żabińska W., Banaś A. (2019), Nowe Przygody Olka i Ady. Litery i liczby. Poziom BB+. Cz. 1. Kielce, MAC Edukacja.

Żaba-Żabińska W., Skrobacz M. (2020), Odkrywam siebie. Przewodnik metodyczny. Poziom BB+. Cz. 1. Kielce, MAC Edukacja.

\section{WSiP}

Dymarska J., Hanisz J., Kołaczyńska M., Nadarzyńska B. (2017), Nowi Tropiciele. Podręcznik. Klasa 1, cz. 1, 2. Warszawa, WSiP.

Idzikowska-Guzy A., Janus E. (2018), Plac zabaw. Sześciolatek. Roczne przygotowanie przedszkolne. Karty pracy 1 . Warszawa, WSiP.

\section{JUKA}

Faliszewska J., Lech G. (2020), Ja i moja szkoła na nowo. Podręcznik dla klasy 1. Cz. 1, 2. Warszawa, Wydawnictwo Juka. 